\title{
n-HEXANE ISOMERIZATION OVER NICKEL-CONTAINING MORDENITE ZEOLITE
}

\author{
Lyubov Patrylak ${ }^{1,}$, Mariya Krylova ${ }^{1}$, Oleksandra Pertko ${ }^{1}$, \\ Yuliya Voloshyna ${ }^{1}$, Angela Yakovenko ${ }^{1}$
}

https://doi.org/10.23939/chcht14.02.234

\begin{abstract}
Nickel-containing mordenite samples were synthesized by impregnation from aqua's solution of nickel nitrate. Porous and catalytic characteristics of the catalysts were studied by means of low temperature nitrogen adsorption/desorption and micropulse n-hexane isomerisation. The maximum isomer yields are $10-12 \mathrm{wt} \%$ for $1-5 \mathrm{wt} \% \mathrm{Ni}$ content at $523-573 \mathrm{~K}$.
\end{abstract}

Keywords: $n$-hexane isomerization, mordenite zeolite, activity, nickel, palladium, activity, selectivity.

\section{Introduction}

The isomerization of $n$-alkanes is a process of great importance for the oil refining industry. This reaction transforms linear alkanes into branched ones, which have higher octane numbers and therefore utilize light gasoline fraction of atmosphere refining [1-6]. Usually, branched paraffins are obtained by isomerization over bifunctional catalysts, which have Broensted and Lewis acidic and hydrogenating-dehydrogenating active sites [7-11]. Mordenite zeolite and alumina are used in the role of acidic support, whereas hydrogenating-dehydrogeneting sites are usually formed by platinum group metals. Alumina based catalysts are the low temperature (403$448 \mathrm{~K})$ ones and those on the basis of mordenite zeolite the middle temperature (523-573 K) ones. Each of them has its advantages and disadvantages. The first type of catalysts, the chlorinated platinum-loaded alumina, despite the higher yields of branched isomers is very sensitive to admixtures (water, sulfur compounds). The second type of catalysts has low sensitivity to water and sulfur. The relatively high costs of platinum group metals make both types of catalysts very expensive. In the role of isomerization catalysts the superacids based on zirconium

\footnotetext{
${ }^{1}$ V.P. Kukhar Institute of Bioorganic Chemistry and Petrochemistry of National Academy of Sciences of Ukraine

1, Murmans'ka St., 02660 Kyiv, Ukraine

凶lkpg@ukr.net

(c) Patrylak L, Krylova M., Pertko O., Voloshyna Yu., Yakovenko A., 2020
}

oxide can also be used $[8,11]$. Nickel, being a $d$-element, is in the same group with palladium and platinum in periodic table, and demonstrates hydrogenating-dehydrogenating properties. A number of researchers investigated bimetallic Ni-Pt zeolite isomerization catalysts [12-15]. It was also found [16] that zeolite ZSM-5 doped by nickel exhibits good parameters in isomerization of linear alkanes.

Therefore, the aim of the present work was the investigation of nickel-containing isomerisation catalysts on the basis of synthetic mordenite zeolite.

\section{Experimental}

Zeolite catalyst samples have been synthesized on the basis of NaM zeolite $\left(\mathrm{SiO}_{2} / \mathrm{Al}_{2} \mathrm{O}_{3}=9.8\right.$, produced by JS "Sorbent", Nizhnij Novgorog, Russia). H-form zeolite (HM) has been obtained by threefold ion exchange of native sodium cations for $\mathrm{NH}_{4}^{+}$from ammonium nitrate $\mathrm{NH}_{4} \mathrm{NO}_{3}$ aqueous solution $(3 \mathrm{~mol} / \mathrm{l})$. Ion-exchange duration was performed at $358 \mathrm{~K}$ for $3 \mathrm{~h}$, followed by calcination in air $(823 \mathrm{~K}, 2 \mathrm{~h})$. Nickel impregnation was applied from nickel nitrate solution $(0.6 \mathrm{~mol} / \mathrm{l})$ in an amount of 1,5 and $15 \mathrm{wt} \%$. The solution was evaporated on a sand bath for $3 \mathrm{~h}$ and dried at $373 \mathrm{~K}$ for $2 \mathrm{~h}$. Then the samples were kept for $6 \mathrm{~h}$ in a stream of hydrogen at $653 \mathrm{~K}$ to the nickel reduction to the null valence state. As a result, the samples NiHM-1, NiHM-5 and NiHM-15 with 1, 5 and 15 wt $\%$ of $\mathrm{Ni}$, respectively, have been obtained.

The adsorption/desorption isotherms of the synthesized samples have been investigated via low-temperature $(77 \mathrm{~K})$ nitrogen adsorption/desorption using Quantachrome Autosorb NOVA 1200e porometer. Parameters of the porous structure were calculated using the software NOVAWin TM. The specific surface areas $\left(S^{B E T}\right)$ have been calculated according to the BET method utilizing the nitrogen adsorption data at $P / P_{s}$ values between 0.06 and 0.2 . The micropores volumes $\left(V_{\text {micro }}^{t}\right)$ and micropores surface areas $\left(S_{\text {micro }}^{t}\right)$ have been estimated using the de Boer $t$-plot method.

X-ray diffraction studies used a standard XRD measurement on DRON-4-07 diffractometer with the Ni 
filtered $\mathrm{CuK}_{\alpha}$ radiation in a reflected beam at the BraggBrentano focus geometry in the range of $2 \theta=5-80^{\circ}$ with a step of 0.05 and $1 \mathrm{~s}$ exposure. Individual intervals were recorded with a step of 0.02 degree and an exposure of $4 \mathrm{~s}$. The phase composition of the samples was determined using the X-ray diffraction data base PDF-2, ICDD, Newton Square, PA. The average size of nickel crystallites was determined from the (111) and (200) X-ray lines broadening utilizing the Scherrer's formula.

Catalytic investigations have been carried out at the laboratory setup with a microreactor. Such testing technique allows to minimize the reaction time on the catalyst bed and to obtain primary transformation products [17], which is useful for reflection on the mechanisms of reactions [17-19].

Catalyst efficiency has been studied in the linear hexane isomerization utilizing the micropulse setup based on gas chromatograph TSVET-104 equipped with a flame ionization detector [20]. High purity hydrogen was used as a carrier gas. The reaction was studied in the temperature range from 473 to $573 \mathrm{~K}$. Linear hexane has been dosed by pulses of $1 \mu l$ using a microsyringe in the top of the reactor. The products and unconverted $n$-hexane were collected in a cooled by liquid nitrogen $(77 \mathrm{~K})$ trap connected with the reactor bottom and analyzed online using a capillary column $(50 \mathrm{~m}, 0.25 \mathrm{~mm}$ inner diameter) with a squalane as the stationary phase after vaporizing by a thermal impulse of $473 \mathrm{~K}$. The temperature in the column thermostat was $323 \mathrm{~K}$.

\section{Results and Discussion}

The low temperature adsorption/desorption nitrogen isotherms for the synthesized samples are shown in Fig. 1. On their basis porous characteristics of the samples have been calculated and summarized in Table 1.

Isotherms are typical ones for micro/mesoporous sorbents, which are characterized by a steep rise at low $P / P_{s}$ values assigned to the formation of equilibrium Langmuir adsorbate monolayers and a hysteresis loops over higher $P / P_{s}$ values [21-24]. Isotherms belong to IVa type with $\mathrm{H} 3$ hysteresis loop according to the classification of IUPAC [21], and this could be related to cylindrical pore channels. The shape of the isotherms and the hysteresis loops both indicate adsorption not only in the micropores, but also on the outer surface of the crystals and mesopores. The presence of the hysteresis loops demonstrates the implementation of capillary condensation in the mesopores that arose not in the result of impregnation by nickel but during the decationation process. In Fig. 2 the differential pores size distribution for investigated samples calculated by DFT method is depicted. The wideporous mordenite type zeolite has two types of microporous channels: $0.29 \times 0.57$ and $0.65 \times 0.7 \mathrm{~nm}$. In addition, mesopores with a radius of about $1 \mathrm{~nm}$ and $2-3 \mathrm{~nm}$ are clearly visible in Fig. 2 . They are practically not changed in the process of nickel impregnation.

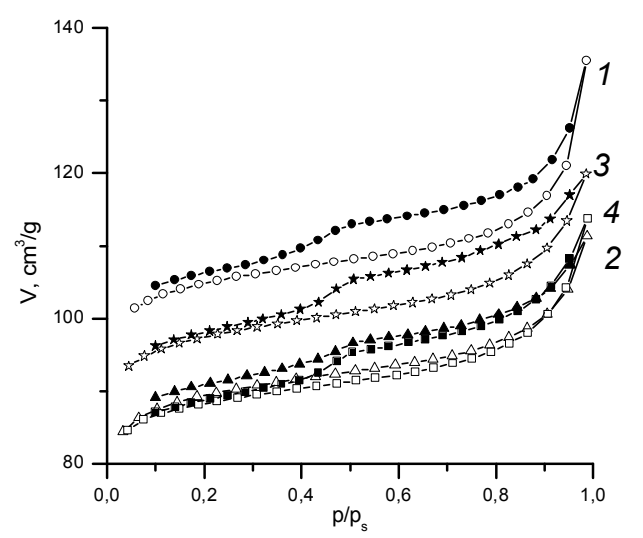

Fig. 1. Low temperature nitrogen adsorption/desorption isotherms for the prepared samples on the basis of synthetic mordenite: HM (1), NiHM-1 (2), NiHM-5 (3) and NiHM-15 (4)

For all catalysts, a slight decrease in the total pore volume due to impregnation has been observed. A sample with $1 \mathrm{wt} \%$ of nickel is characterized by the largest decrease of the micropore surface area after impregnation. Probably, this is due to the minimal size of nickel particles that blocked more inputs into the mordenite channels.

The analysis of X-ray diffraction patterns for synthesized samples (Fig. 3) shows that all catalysts have a crystalline structure corresponding to the structure of MOR zeolite (JCPDS Card \# 29-1257) [24]. XRD phase of mordenite is found to match with the peaks at $2 \theta=6.51$, $9.77,18.07,20.34,26.14,28.89,30.39,37.00,38.92$, $39.75,40.55,41.90,42.62,44.68,46.94,47.98,48.85$ and 49.59. These peaks are characteristic for mordenite zeolite, and correspond to the planes (110), (200), (131), (041), (060), (441), (531), (711), (133), (570), (480), (423), (082), (063), (911), (173), (114) and (204).

Table 1

Porous characteristics of the catalysts on the basis of mordenite zeolite

\begin{tabular}{|c|c|c|c|c|c|}
\hline Sample & $S^{B E T}, \mathrm{~m}^{2} / \mathrm{g}$ & $S_{\text {micro }}, \mathrm{m}^{2} / \mathrm{g}$ & $V_{\Sigma}, \mathrm{cm}^{3} / \mathrm{g}$ & $V_{\text {micro }}^{t} \mathrm{~cm}^{3} / \mathrm{g}$ & Average pore radius, $\mathrm{nm}$ \\
\hline HM & 382 & 365 & 0.21 & 0.16 & 1.10 \\
\hline NiHM-1 & 336 & 319 & 0.17 & 0.13 & 1.02 \\
\hline NiHM-5 & 360 & 342 & 0.19 & 0.14 & 1.03 \\
\hline NiHM-15 & 328 & 310 & 0.18 & 0.13 & 1.07 \\
\hline
\end{tabular}


Three characteristic peaks for nickel $\left(2 \theta=44.5^{\circ}\right.$, $51.8^{\circ}$, and $76.4^{\circ}$ ), corresponding to Miller indices (111), (200), and (222), are also shown in Fig. 3. The latter line (222) is of the lowest intensity. The intensity of peaks increases with the increase of nickel content in the samples. The appearance of these peaks reveals that the resultant particles are pure facecentred cubic nickel at these samples (JCPDS, No. 04-0850). Unfortunately, for small amounts of nickel (1 wt \%), it was difficult to isolate the reflexes to calculate the size of its particles due to the overlap of zeolite and nickel lines, but its presence in the NiHM-1 sample indicates a change in the intensity
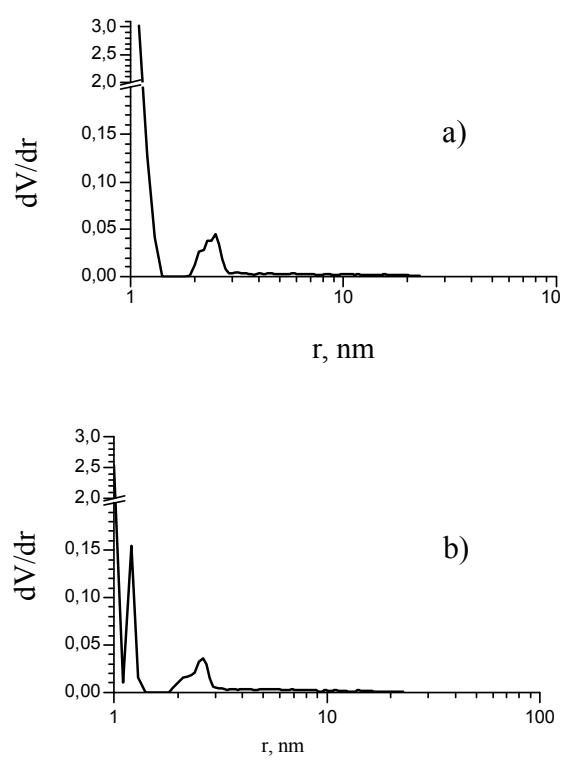

of the line (111) and an increase in the background level in comparison with a sample of HM (Fig. 4). For the samples of NiHM-5 and NiHM-15, in addition to crystalline nickel reflexes, even more background elevations are observed.

The average size of nickel particles for samples NiHM-5 and NiHM-15 was 20 and $22 \mathrm{~nm}$, respectively (Ni cubic, JCPDS Card \#4-850). Based on the received pore size distribution for the investigated zeolites and the size of the nickel particles, we can talk about the localization of the latter only on the outer surface of the zeolite crystals.

Fig. 2. Differential pore size distributions calculated by DFT method for HM (a), NiHM-1 (b), NiM-5 (c) and NiHM-15 (d) samples

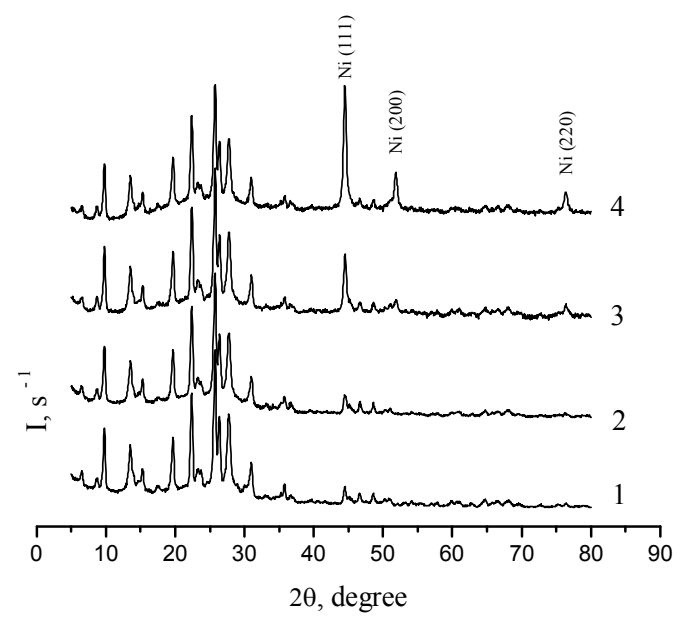

Fig. 3. X-ray powder diffraction patterns of HM (1) and nickel-containing mordenite catalysts NiHM-1 (2), NiHM-5 (3) and NiHM-15 (4)
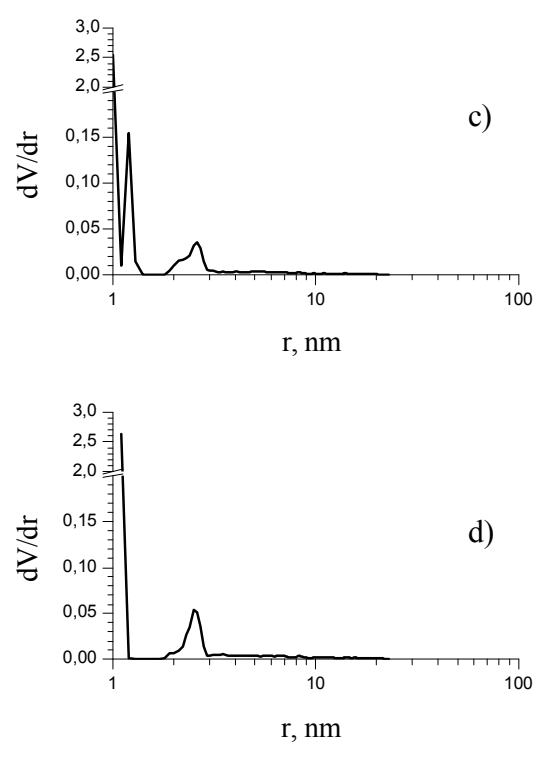

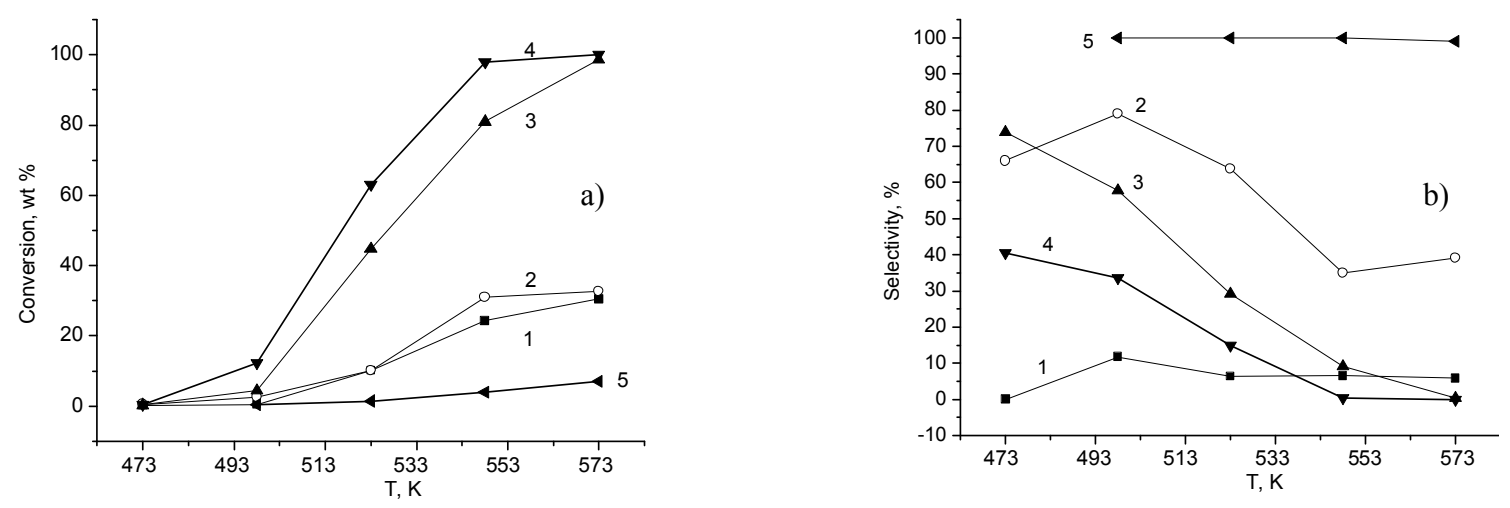

Fig. 5. $n$-Hexane conversion (a) and isomers selectivity (b) for HM (1), NiHM-1 (2),

NiHM-5 (3), NiHM-15 (4) and PdHM (5) samples

Table 2

Yields of isomerization products in micro pulse linear hexane isomerization over Ni-containing mordenite samples

\begin{tabular}{|l|c|c|c|c|}
\hline \multirow{2}{*}{ Sample } & \multicolumn{4}{|c|}{ Yield at different temperatures, wt \% } \\
\cline { 2 - 5 } & $498 \mathrm{~K}$ & $523 \mathrm{~K}$ & $548 \mathrm{~K}$ & $573 \mathrm{~K}$ \\
\hline HM & 1.0 & 1.5 & 2.0 & 2.0 \\
\hline NiHM-1 & 2.0 & 5.0 & 10.0 & 11.0 \\
\hline NiHM-5 & 2.0 & 12.0 & 6.0 & 1.0 \\
\hline NiHM-15 & 4.0 & 8.0 & 1.0 & 0.5 \\
\hline
\end{tabular}

Among the products of isomerization of $n$-hexane there are both isomers $i \mathrm{C}_{6}$ and cracking products $\mathrm{C}_{1}-\mathrm{C}_{5}$. Conversion over the samples on the basis of mordenite (Fig. 5a) strongly depends on the content of hydrogenating-dehydrogenating components and increases with its increase for the catalysts with 1,5 and $15 \mathrm{wt} \%$ of nickel. Thus, at $548 \mathrm{~K}$ this increase ranges from $\sim 25$ to 75 and $100 \mathrm{wt} \%$, respectively. Catalyst with $1 \mathrm{wt} \% \mathrm{Ni}$ converts at the level of the original HM sample. But impregnation of $1 \%$ of $\mathrm{Ni}$ causes a sharp increase in catalyst selectivity for hexane isomers (Fig. 5b), which remains the highest among four samples within the temperature range. As a result, regarding the isomers yield (Fig. 5), this catalyst is not inferior to other nickel-containing samples, but its maximum value is achieved at the temperature by $25-50 \mathrm{~K}$ higher than that for the catalysts with higher nickel content. This is obviously due to high activity of latter ones relative to hexane conversion. The increase in temperature increases the catalysts selectivity relative to cracking products (Fig. $5 \mathrm{~b}$ ) and they become unable to maintain a high yield of the target products. For comparison in Fig. 5 the results obtained over palladiumcontaining mordenite [20] are shown. This catalyst is characterized by a high selectivity at relatively low activity.

Thus, at $523-573 \mathrm{~K}$ the highest yield of hexane isomers (Table 2) on the mordenite based samples is 10 $12 \mathrm{wt} \%$ for Ni content of $1-5 \mathrm{wt} \%$.
Since a spatially close combination of the Broensted and Lewis acid centers, as well as the hydrogenatingdehydrogenating centers (metal nickel in our case), is necessary for the realization of linear hydrocarbon structures isomerization, the conversion obviously occurs not in the micropores of zeolite, but on the external surface of the crystals. The latter is relatively small $\left(S_{e x}=S^{B E T}-S_{\text {micro }}^{t}=17-18 \mathrm{~m}^{2} / \mathrm{g}\right.$, Table 1$)$. The resulting yields are smaller than those observed over Ni-containing pentasil zeolites (up to 20-25\% [16], for which it was possible to obtain nickel particles with smaller size from 8 9 to $16-18 \mathrm{~nm}$. Therefore, in order to raise the yields, it is expedient, firstly, to expand the pore size of the mordenite, for example, by carrying out an additional dealumination of the zeolite lattice, and, secondly, to reduce the size of the impregnated metal particles.

Thus, the sample with the best ratio of the selectivity/ activity parameters is NiHM-5, and the optimum isomerization temperature is $523 \mathrm{~K}$. The NiHM-1 catalyst, showing similar yields, requires temperatures higher by $25-50 \mathrm{~K}$. The characteristics of these samples are the closest to the isomerization results over palladiumcontaining mordenite [20].

\section{Acknowledgments}

The authors express their gratitude to the senior researcher Olena I. Oranska, $\mathrm{PhD}$, leading engineer Yuriy I. Gornikov (O.O. Chuiko Institute of Surface Chemistry, 
NAS of Ukraine) for conducting an X-ray diffraction analysis of the samples, and leading engineer Dmytro V. Molodyi (V.P. Kukhar Institute of Bioorganic Chemistry and Petrochemistry, NAS of Ukraine) for adsorption measurements.

The publication contains the results achieved due to the grant of the President of Ukraine on competitive projects F74/179-2017 of the State Fund for Fundamental Research.

\section{References}

[1] Primo A., Garcia H.: Chem. Soc. Rev., 2014, 43, 7548. https://doi.org/10.1039/C3CS60394F

[2] Liu S., Ren J., Zhang H. et al.: J. Catal., 2016, 335, 11. https://doi.org/10.1016/j.jcat.2015.12.009

[3] Dhar A., Vekariya R., Sharma P.: Petroleum, 2017, 3, 489. https://doi.org/10.1016/j.petlm.2017.02.001

[4] Izutsu Y., Oku Y., Hidaka Y. et al.: Catal. Lett., 2013, 143, 486. https://doi.org/10.1007/s 10562-013-0973-y

[5] Ghouri A., Usman M.: J. Chem. Soc. Pak., 2017, 39, 919.

[6] Dhar A., Vekariya R., Bhadja P.: Cogent Chem., 2018, 4, 1514686. https://doi.org/10.1080/23312009.2018.1514686

[7] Dhar A., Dutta A., Castillo-Araiza C. et al.: Int. J. Chem. Reactor Eng., 2016, 14, 795. https://doi.org/10.1515/ijcre-20150052

[8] Tamizhdurai P., Lavanya M., Meenakshisundaram A. et al.: Adv. Por. Mater., 2017, 5, 169.

https://doi.org/10.1166/apm.2017.1127

[9] Yun S., Seong M., Park Y. et al.: J. Nanosci. Nanotechnol., 2015, 15, 647. https://doi.org/10.1166/jnn.2015.8328

[10] Patrylak L.: Adsortp. Sci. Technol., 1999, 17, 115. https://doi.org/10.1177/026361749901700205

[11] Brei V.: Theor. Experim. Chem., 2005, 41, 165. https://doi.org/10.1007/s11237-005-0035-7

[12] Yoshioka C., Garetto T., Cardoso D.: Catal. Today, 2005, 107108, 693. https://doi.org/10.1016/j.cattod.2005.07.056

[13] Jordao M., Simoes V., Cardoso D.: Appl. Catal. A, 2007, 319, 1. https://doi.org/10.1016/j.apcata.2006.09.039
[14] Lima P., Garetto T., Cavalcante C.L.Jr. et al.: Catal. Today, 2011, 172, 195. https://doi.org/10.1016/j.cattod.2011.02.031

[15] Martins G., dos Santos E., Rodrigues M. et al:: Modern Res. Catal., 2013, 2, 119. https://doi.org/10.4236/mrc.2013.24017 [16] Patrylak L., Krylova M., Pertko O. et al.: J. Porous Mater., 2019, 26, 861. https://doi.org/10.1007/s10934-018-0685-1

[17] Patrylak L.: Adsorp. Sci. Technol., 2000, 18, 399. https://doi.org/10.1260/0263617001493512

[18] Patrylak K.,, Patrylak L.,, Repetskyi I.: Theor. Experim. Chem., 2013, 49, 143. https://doi.org/10.1007/s11237-013-9308-8

[19] Patrylak K., Patrylak L., Voloshyna Yu. et al.: Theor. Experim. Chem., 2011, 47, 205. https://doi.org/10.1007/s11237-011-9205-y [20] Patrylak L., Manza I., Vypirailenko V. et al.: Theor. Experim. Chem., 2003, 39, 263. https://doi.org/10.1023/A:1025729530977 [21] Rouquerol F., Rouquerol J., Sing K.: Adsorption by Powders and Porous Solids. Principles, Methodology and Applications. Academic Press, San Diego 1999.

[22] Patrylak L., Likhnyovskyi R., Vypyraylenko V. et al.: Adsorpt. Sci. Technol., 2001, 19, 525. https://doi.org/10.1260/0263617011494376

[23] Patrylak L.: Zh. Phys. Khim., 2005, 79, 1658.

[24] Smail H., Shareef K., Ramli Z.: Austral. J. Bas. Appl. Sci., 2017, 11, 27. http://www.ajbasweb.com/old/ajbas/2017/January/27-34.pdf

Received: October 08, 2018 / Revised: October 31, 2018 / Accepted: January 28, 2019

\section{ІЗОМЕРИЗАЦІЯ Н-ГЕКСАНУ НА НІКЕЛЬВМІСНОМУ ЦЕОЛІТІ ТИПУ МОРДЕНІТУ}

Анотація. Синтезовано зразки нікельвмісного морденіту внаслідок просочування із водних розчинів нітрату нікелю. 3 використанням методу низькотемпературної адсорбиії десорбиії азоту та мікроімпульсної ізомеризації н-гексану вивчено пористі та каталітичні властивості. За температур 523-573 К максимальні виходи ізомерів становлять 10-12\% мас. для вмісту Ni 1-5\% мас.

Ключові слова: ізомеризачія н-гексану, цеоліт типу морденіту, нікель, паладій, активність, селективність. 